\title{
PENGARUH PENCUACAAN ALAMI TERHADAP PRODUK LATEKS KARET ALAM BERPENGISI TEPUNG KULIT PISANG YANG DIPUTIHKAN DENGAN HIDROGEN PEROKSIDA
}

\author{
Emelya Khoesoema, Erick Kamil, Hamidah Harahap \\ Departemen Teknik Kimia, Fakultas Teknik, Universitas Sumatera Utara, \\ Jalan Almamater Kampus USU Medan 20155, Indonesia \\ Email: emelya_khoesoema@yahoo.com
}

\begin{abstract}
Abstrak
Pengaruh tepung kulit pisang yang telah diputihkan sebagai pengisi produk lateks karet alam terhadap sinar matahari dan cuaca dengan variasi pembebanan pengisi tepung kulit pisang yang diputihkan.Tepung kulit pisang yang telah dihasilkan dikeringkan kemudian diputihkan dengan hidrogen peroksida dan dibuat menjadi sistem dispersi.Lateks karet alam dicampur dengan tepung kulit pisang yang telah diputihkan dengan pembebanan pengisi 0 hingga 20 bsk (bagian seratus karet).Produk lateks karet alam yang dihasilkan kemudian digantung di udara bebas dan terpapar terhadap sinar matahari serta cuaca. Hasil degradasi produk lateks karet alam berpengisi tepung kulit pisang yang telah diputihkandengan hidrogen peroksida dievaluasi dengan perhitungan kehilangan berat dan analisis Fourier transform infrared spectroscopy (FTIR).Produk lateks karet alam mengalami kehilangan berat setelah terpapar terhadap sinar matahari dan cuaca dari waktu 1 hingga 16 minggu karena proses foto-oksidasi.
\end{abstract}

Kata kunci: lateks, tepung kulit pisang, biodegradasi, hidrogen peroksida, kehilangan berat

\begin{abstract}
The effect of exposing bleached banana skin powder-filled natural rubber products to sun light and weather with variation of bleached banana skin powder filler loading. Banana skin powder was dried and bleached with hydrogen peroxide and made into disperse system. Natural rubber latex was compounded with bleached banana skin powder with filler loading of 0 to $20 \mathrm{phr}$ (per hundred rubber). Natural rubber latex products, which were produced, were hung in air and exposed to sun light and weather. The degradation of bleached banana skin powder-filled natural rubber products were evaluated by calculating weight loss of samples and performing Fourier transform infrared spectroscopy (FTIR) test. Natural rubber latex lost weight after exposure to sun light and weather from 1 to 16 weeks due to photo-oxidation process.
\end{abstract}

Keywords: latex, banana skin powder, biodegradation, hydrogen peroxide, weight loss

\section{Pendahuluan}

Selama penggunaan bahan polimer, bahan polimer akan terpapar terhadap lingkungan seperti panas, kelembaban, oksigen, ozon dan sebagainya. Berbeda dengan polimer lainnya, karet alam sangat tahan terhadap degradasi karena pada rantai utama molekul karet alam terdapat ikatan rangkap.Degradasi karet alam pada umumnya dipercepat oleh panas, kelembaban, sinar, ozon, radiasi dan sebagainya [1].

Pada produk karet alam, degradasi pada umumnya diakibatkan oleh molekul oksigen dan ozon. Hal ini disebabkan karena karet alam mengandung rantai yang memiliki ikatan tak jenuh yang mudah diserang oleh molekul oksigen dan ozon.Degradasi oleh ozon pada umumnya mengakibatkan perubahan warna dan keretakan pada permukaan produk karet alam. Sementara degradasi oleh oksigen dan panas mengakibatkan produk karet alam menjadi lebih lembut $[1,2]$.

Pemberian pengisi akan mempengaruhi sifat komposit polimer, termasuk sifat degradasi dan stabilitas polimer [3]. Pengisi juga digunakan untuk berbagai tujuan di antaranya sebagai penguat, dan pengurangan biaya [4].Beragam pengisi digunakan untuk karet alam secara komersil pada umumnya adalah tanah liat, kalsium karbonat, dan titanium dioksida [5]. Akhir-akhir ini penggunaan serat alam sebagai pengisi komersil telah diteliti oleh peneliti karena serat alam dapat diperbaharui, banyak tersedia, murah, dan ramah lingkungan [6].

Penelitian mengenai degradasi dengan penggantungan di udara produk lateks karet alam berpengisi tepung kulit pisang juga telah dilakukan oleh Hamidah Harahap et al dan dilaporkan bahwa produk lateks karet alam berpengisi tepung kulit pisang dapat didegradasi [7].Tepung kulit pisang merupakan limbah di Indonesia yang pemanfaatannya belum begitu banyak, sehingga akan digunakan sebagai pengisi karet alam.Selain itu, Anhwange melaporkan bahwa kulit pisang mengandung serat sebanyak $31,70 \%$ [11] sehingga merupakan potensi sumber serat alami untuk diolah menjadi pengisi polimer. Penggunaan kulit pisang yang merupakan sampah organik dari buah pisang juga bisa mengurangi volume sampah atau limbah yang akan mencemari lingkungan.

Tepung kulit pisang yang dikeringkan akan berwarna hitam sehingga akan mempengaruhi 
warna dari produk lateks karet alam. Tepung kulit pisang terlebih dahulu diputihkan dengan hidrogen peroksida dan kemudian dicampurkan dengan lateks karet alam. Degradasi sampel dievaluasi berdasarkan pengurangan berat sampel dan analisis Fourier transform infrared spectroscopy (FTIR).

\section{Teori}

Lateks karet alam merupakan dispersi koloid yang stabil dari cis-1,4-poliisoprena dengan massa molekul yang tinggi pada media cair [8].Sebelum lateks digunakan untuk menghasilkan produk perlu dilakukan sambung-silang terlebih dahulu. Tujuan penyambung-silangan lateks adalah untuk menentukan kekuatan film lateks yang dihasilkan agar mencapai spesifikasi yang diinginkan. Proses penyambung-silangan bagi lateks dilakukan dengan mencampurkan bahan tambahan tertentu kedalam lateks. Bahan tambahan didalam campuran lateks pada mulanya memiliki ukuran butiran yang lebih besar dari ukuran partikel lateks itu sendiri. Jadi bahan tambahan ini perlu disediakan dalam bentuk dispersi supaya dapat disebarkan dengan baik dalam partikel lateks [9]. Bahan tambahan (bahan kuratif) yang biasa digunakan didalam pencampuran lateks mempunyai fungsi tertentu yang dinyatakan sebagai berikut: bahan vulkanisasi, bahan pencepat, bahan pengaktif, bahan penstabil, bahan antioksidan dan pengisi [10].

\section{Metodologi Penelitian}

Penyediaan Pengisi

Kulit pisang dipotong hingga panjang $1 \mathrm{~cm}$ dan dikeringkan pada suhu $100^{\circ} \mathrm{C}$ selama 24 jam.Kulit pisang dihancurkan dan diayak hingga diperoleh tepung kulit pisang dengan ukuran 100 mesh.Tepung kulit pisang diputihkan dengan larutan hidrogen peroksida 6\%.Larutan pemutih ini terdiri dari larutan $6 \%$ hidrogen peroksida, ditambah larutan natrium hidroksida $10 \%$ untuk menaikan $\mathrm{pH}$ hingga 11.Tepung kulit pisang diputihkan dalam larutan pemutih sambil diaduk pada suhu $80^{\circ} \mathrm{C}$ selama 1 jam.Tepung kulit pisang yang telah diputihkan dicuci dengan air hingga $\mathrm{pH}$ netral dan dibuat ke dalam sistem dispersi. Sistem dispersi terdiri dari tepung kulit pisang yang telah diputihkan, air dan polivinil pirolidon dengan perbandingan berat 15:83:2 dan dicampur selama 24 jam.
Pra-vulkanisasi dan vulkanisasi

Lateks dengan kadar amoniak tinggi dicampur dengan bahan kuratif dan di-pra-vulkanisasi selama 15 menit pada suhu $70{ }^{\circ} \mathrm{C}$. Karet yang telah di-pravulkanisasi dicampur dengan dispersi tepung kulit pisang dengan kadar pengisi 5 bsk, 10 bsk, 15 bsk dan 20 bsk. Film lateks karet alam dibentuk dengan teknik pencelupan yang mana terlelebih dahulu dengan membersihkan pembentuk sebelum mencelupkannya ke dalam senyawaan latex karet alam. Film latex karet alam yang telah dicelup divulkanisasi pada suhu $100{ }^{\circ} \mathrm{C}$.

Tabel 1. Bahan-bahan senyawaan latex pravulkanisasi

\begin{tabular}{lc}
\hline \multicolumn{1}{c}{ Bahan } & Berat basah (gr) \\
\hline High Ammonia Lateks & 166,67 \\
Larutan Sulfur 50\% & 3 \\
Larutan ZDEC $^{\dagger} 50 \%$ & 3 \\
Larutan ZnO 30\% & 0,83 \\
Larutan Antioksidan 50\% & 2 \\
Larutan KOH 10\% & 3 \\
Pengisi (tepung kulit pisang) & $0,5,10,15,20,25$ \\
\hline \multicolumn{2}{c}{+ ZDEC: Zinc Diethylditiocarbamate }
\end{tabular}

Untuk proses degradasi, produk lateks karet alam berpengisi tepung kulit pisang yang telah diputihkan dengan hidrogen peroksida ditimbang dan dicatat massa dari setiap sampel yang akan diuji. Kemudian sampel tersebut digantung pada tempat yang terpapar sinar matahari dan cuaca. Proses menggantung sampel, dilakukan selama 1minggu, hingga 16 minggu. Sampel yang telah terdegradasi dianalisa.

\section{Hasil}

Hasil penelitian menunjukkan bahwa kehilangan berat produk film lateks karet alam akibat biodegradasi sebanding dengan lama penggantungan. Produk lateks karet alam 0 bsk menunjukan kehilangan berat yang paling besar yaitu 27,4678\%. Semakin banyak pembebanan pengisi, maka semakin kecil persentase kehilangan berat. Persentase kehilangan berat yang paling kecil pada adalah produk lateks karet alam 20 bsk sebesar 9,3750 \%. Sedangkan persentase kehilangan berat produk karet lateks karet alam dengan pembebanan pengisi 15 bsk; $10 \mathrm{bsk}$; dan 5 bsk adalah 9,7046\%; 13,1780\% dan 19,3277\% secara berurutan. 


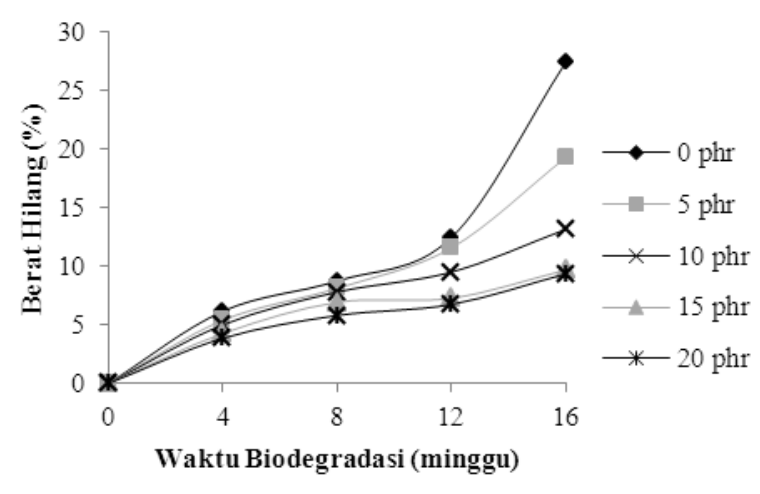

Gambar 1. Pengaruh pembebanan pengisi terhadap biodegradasi produk lateks karet alam dengan metode penggantungan

Kehilangan berat yang paling besar adalah produk lateks karet alam yang tanpa pembebanan pengisi (0 bsk).Semakin ditambahnya pembebanan pengisi, maka kemampuan terdegradasi semakin kecil.Hal ini terlihat dari kehilangan berat yang semakin kecil seiring dengan bertambahnya pembebanan pengisi.Produk lateks karet alam 0 bsk setelah digantung dari 1 hingga 16 minggu menunjukan sifat yang lengket dan lembut serta perubahan warna menjadi semakin gelap. Karet alam apabila teroksidasi oleh oksigen yang mengakibatkan pemutusan ikatan rangkap, maka akan menjadi lengket dan telah menjadi sifat alami karet alam [13]. Sifat yang lengket dan lembut ini karena perusakan sambung silang oleh oksidasi oksigen dan ultraviolet sinar matahari [1, 12]. Pembebanan 5 bsk juga menunjukan sifat yang hampir sama seperti sifat produk lateks karet alam yang tidak diberikan pengisi ( 0 bsk), sementara pembebanan yang semakin banyak mengakibatkan produk lateks karet alam yang digantung selama 16 minggu menjadi rapuh, tetapi tidak lengket dan warna tidak berubah.Hal ini disebabkan pengisi juga dapat menyebabkan sinar ultraviolet matahari tidak dapat menembus matriks karet alam, sehingga degradasi hanya terjadi pada permukaan karet dan timbul keretakan pada permukaan karet [12].

Pemaparan sampel terhadap cuaca mengakibatkan berbagai reaksi terjadi di dalam produk lateks karet alam, yang mengakibatkan perubahan hasil spektrum FTIR jika dibandingkan sampel setelah penggantungan dan sebelum penggantungan. Dapat dilihat pada Gambar 2 bahwa ada kemunculan dan kehilangan dari beberapa puncak pada spektrum FTIR. Gugus karbonil $(\mathrm{C}=\mathrm{O})$ pada daerah $1724,36 \mathrm{~cm}^{-1}$ (a) dan $1743,65 \mathrm{~cm}^{-1}$ (b) dan gugus hidroksil (O-H) $3282,84 \mathrm{~cm}^{-1}$ (a) dan 3566,38 $\mathrm{cm}^{-1}$ (b) terdapat pada sampel yang belum dan sudah digantung. Sebelum penggantungan terdapat puncak pada $2908,65 \mathrm{~cm}^{-1}$ (a) dan setelah penggantungan muncul puncak 2939,52 $\mathrm{cm}^{-1}$ dan $2868,15 \mathrm{~cm}^{-1}$ yang merupakan puncak untuk gugus alkane $\left(\mathrm{CH}_{3}\right)$. Sebelum penggantungan, gugus alkane menunjukan puncak yang tajam, sementara sesudah penggantungan, puncak menjadi datar dan kehilangan intensitas. Gugus polisakarida pada puncak $1031,92 \mathrm{~cm}^{-1}$ dan $1002,98 \mathrm{~cm}^{-1}$ pada sampel sebelum penggantungan juga hilang. Hal ini mengindikasikan terjadi perubahan senyawa pada sampel. Setelah penggantungan, muncul puncak yang lebar $3213,41 \mathrm{~cm}^{-1}$ (b) yang merupakan gugus asam karboksilat, demikian pula muncul puncak pada daerah $1743,65 \mathrm{~cm}^{-1}$ (b) yang merupakan gugus karbonil dari ikatan ester. Serangan ozon mengakibatkan terbentuknya ozonida yang tidak stabil yang akan membentuk produk yang beragam berupa asam, ester, keton, dan aldehida [12].

\section{Kesimpulan}

Penggunaan tepung kulit pisang yang telah diputihkan sebagai pengisi produk film lateks karet alam mengakibatkan proses degradasi menjadi lebih lambat. Hasil FTIR menunjukan bahwa produk lateks karet alam berpengisi tepung kulit pisang yang diputihkan juga mengalami degradasi. Setelah penggantungan, produk lateks karet alam yang tidak berpengisi menjadi lebih lembut dan lengket karena oksidasi oksigen dan degradasi oleh sinar ultraviolet sementara produk karet berpengisi tepung kulit pisang yang diputihkan tidak begitu lembut karena sinar ultraviolet tidak dapat menembus matriks karet karena adanya pengisi, sehingga lebih tahan untuk produk yang terpapar sinar matahari dan cuaca. 


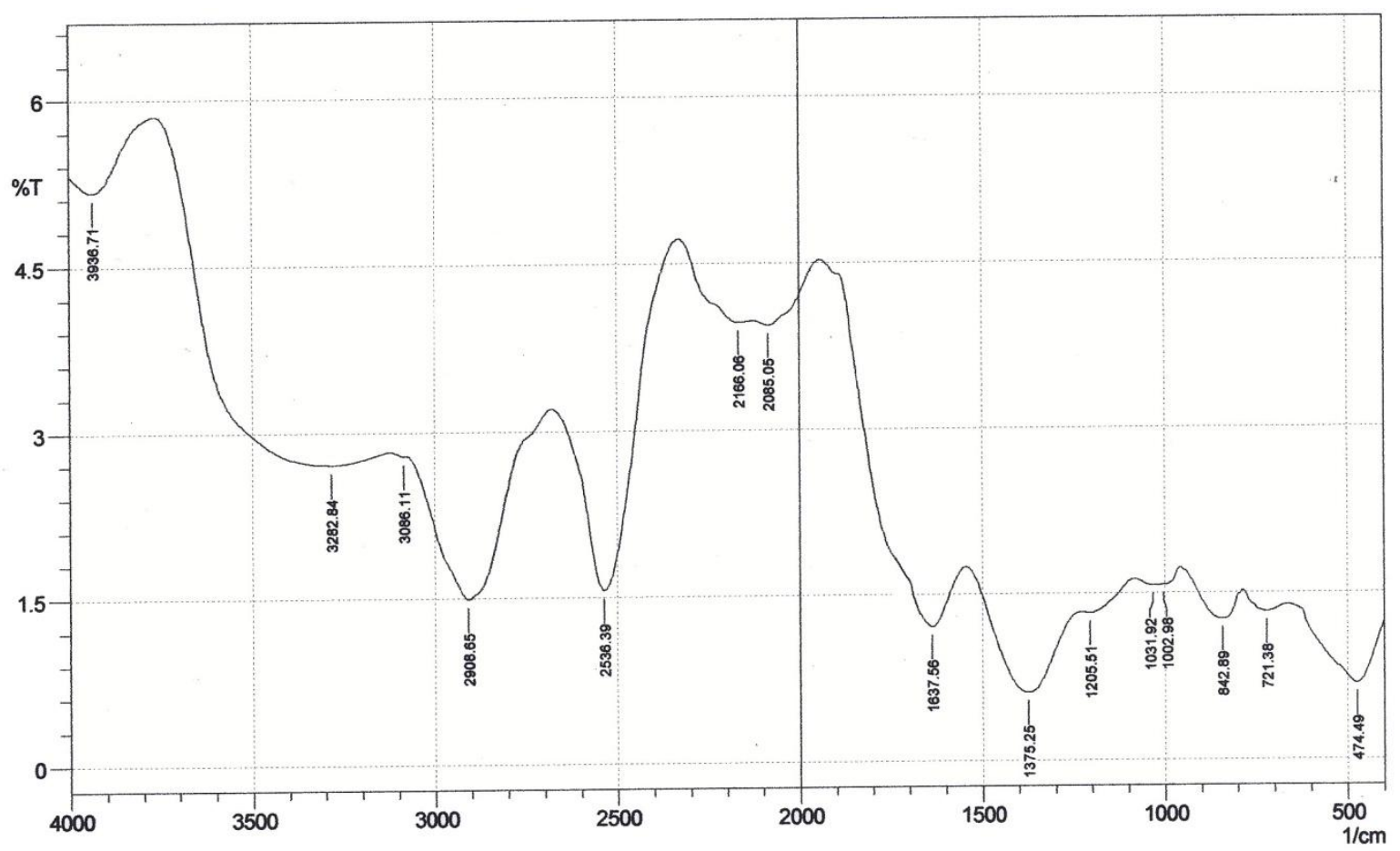

(a)

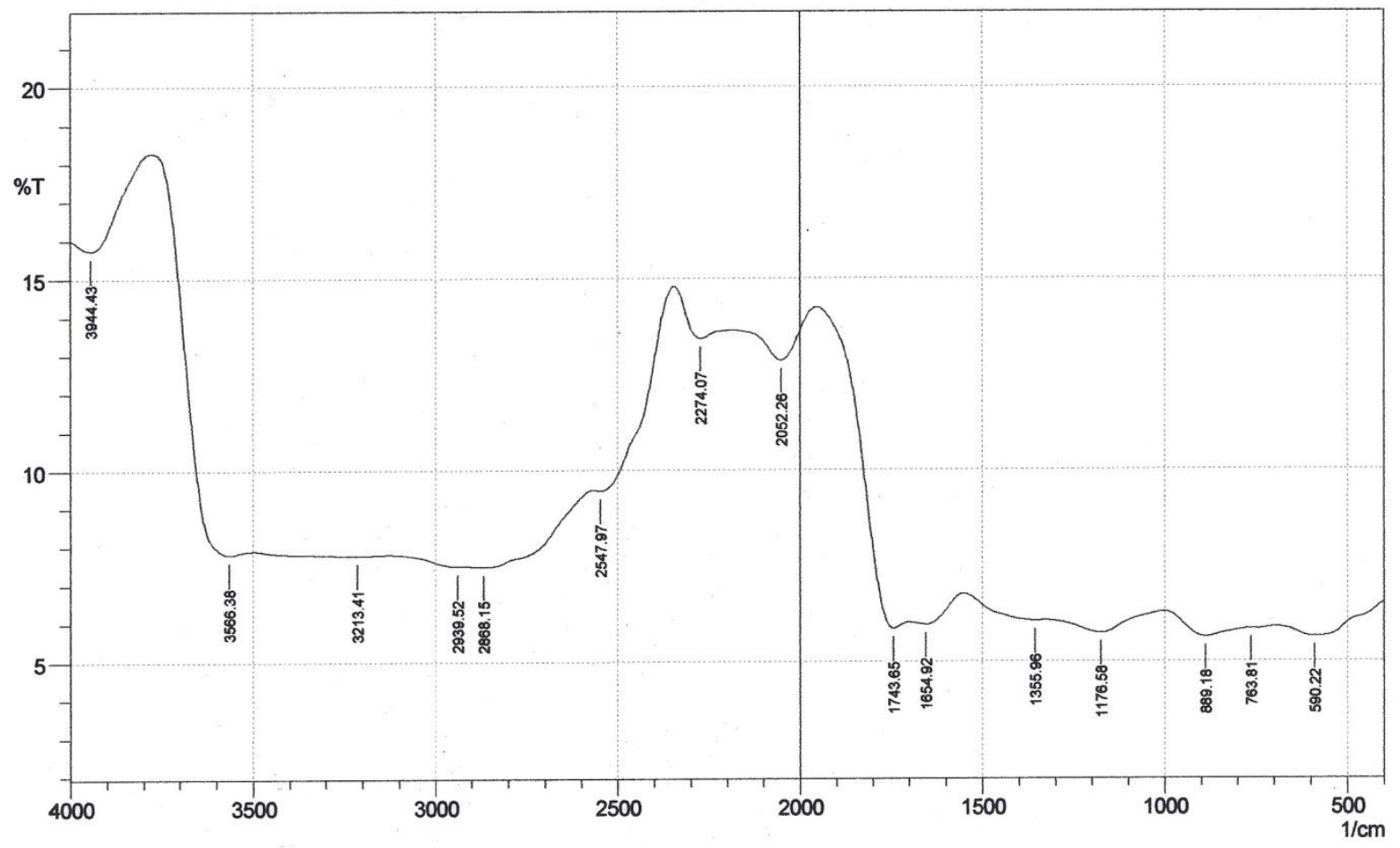

(b)

Gambar 2. Spektrum FTIR dari Produk Lateks Karet Alam Berpengisi Tepung Kulit Pisang yang Diputihkan dengan Hidrogen Peroksida 20 bsk Sebelum (a) dan Sesudah Penggantungan (b)

\section{Daftar Pustaka}

[1] V.S. Vinod, S. Varghese, dan B. Kuriakose. Polym. Deg.and Stab. 75, pp.405-412, 2002.

[2] Datta R.N. dan Huntink. Degradation and Protection: Current Topics in Elastomer Research. Penerbit Taylor \& Francis, pp.61, 2008.
[3] M.T. Bryk. Degradation of Filled Polymers. Penerbit Ellis Horwood, London, pp.101, 1991.

[4] N. Rattanasom, T. Saowapark, dan C. Deeprasertkul. Polym. Test. 26 pp. 369-377, 2006. 
[5] J. A. Kent. Kent and Riegel's Handbook of Industrial Chemistry and Biotechnology. Penerbit Springer, New York. pp. 695, 2007.

[6] M. J. John, R. D. Anandjiwala, dan S. Thomas. Penerbit Old City Publishing, Philadelphia. pp. 201-202, 2008.

[7] H. Harahap, A. Boy dan N. Sitorus. J. Ilmu Pengetahuan dan Terapan Reintek 6(1), pp.23-30, 2011.

[8] D. C. Blackley. Polymer Latices Science and Technology. Penerbit Chapman \& Hall, London. pp.1-2, 1997.

[9] Indra Surya. Bahan Ajar Teknologi Karet, Universitas Sumatera Utara, 2006.

[10] J. E. Mark, E. Burman, dan F. R. Eirich. The Science and Technology of Rubber. Edisi ke3. Penerbit Elsevier, Inc., New York. pp. 130131, 2005.

[11] B. A. Anhwange, T. J. Ugye dan T. D. Nyiaatagher. E. J. of Env., Agri., and Food Chem. 8(6), pp.437-442, 2008.

[12] K. Muniandy, H.Ismail, dan N. Othman. BioRes. 7 pp. 3999-4011, 2012.

[13] G. R. Hamed, A. N. Gant, dan K. Baranwal. Elastomer Technology. Penerbit The Rubber Division ACS, Ohio. pp.16, 2003. 